\title{
ARCHIPIÉLAGO EN LÍNEAS
}

\author{
Eduardo RAMOS IZQUIERDO \\ Université Paris Sorbonne - Paris IV
}

\section{1}

\section{Desde los orígenes}

Escribo porque he vivido y he leído, escribo por mi pasión por la lectura de las formas breves como el cuento y los relatos mitólogicos. Recuerdo con intensidad que en mi infancia frecuenté con avidez los cuatro volúmenes de una enciclopedia de fábulas que procedían de todos los continentes; recuerdo también la edición de Sopena de las Mil y una noches, así como las páginas de alguna antología de mitos grecolatinos. Creo ver allí un precedente de mi escritura de ficción.

No obstante, mis primeras páginas comprendieron otras disciplinas. Mi fruición por la historia de México se tradujo en la escritura de unas breves biografías de algunos próceres de la Independencia.

Efectivamente, toda lectura deja sus residuos. La obra literaria está siempre nutrida de nuestras lecturas: se escribe también porque se ha leído.

\section{Del pecado de la individualidad}

Qué se le va a hacer: he rechazado consciente y voluntariamente las etapas de lo que podría llamarse una carrera literaria estándar. Confieso, para bien o para mal, que no aprendí a escribir en ningún taller literario ni estuve bajo la tutela oral de ningún escritor: he preferido la secreta lectura de algunos grandes faros. Tampoco concursé para becas de creadores ni canjeé la escritura de reseñas ajenas por la publicación de mis ejercicios de ficción. Cuántos errores.

Lo que en realidad sucede es que siempre he visto con desconfianza la etiqueta de «escritor profesional», porque la escritura literaria constituye para mí una aventura personal e independiente. Mi gusto por ella estriba en el hecho de experimentar esa sensación -intensa hasta el vértigo- de libertad. Libertad: ilusión, quimera, esperanza: quizá. Libertad: una búsqueda incesante: ciertamente.

Imposible abstraerse al tiempo y a las modas. Estamos, querámoslo o no, en él y en ellas. No obstante, ese gusto por la libertad me ha ahorrado compromisos u obligaciones de grupos, de corrientes, de editoriales comerciales.

Insisto nunca he sido ni seré un escritor profesional. La escritura nunca ha sido mi modus vivendi (por fortuna) ni ha estado sujeta a las consignas de un ningún patrón (llamase agente o editor).

Escribo simplemente por necesidad, por placer, por pasión. 


\section{De la escritura literaria}

La literatura es sinónimo de imaginación, es decir, de ficción. Su fuerza reside en su alta capacidad de invención.

Si concibo la escritura como algo personal, discreto, casi secreto, la escritura es ante todo un ejercicio subjetivo que quizá sea la mejor manera de buscar y alcanzar lo colectivo y lo universal.

Sus grandes temas principales son eternos y eternamente modulables. Me parece que son la vida, la muerte, el amor y, en alguna medida, la escritura misma. Son capaces de resistir imitaciones y rupturas, homenajes y profanaciones, toda clase de onomatopeyas.

Ni modo, la verdad de Perogrullo: lo esencial en la prosa de ficción es el arte de contar, de contar una historia.

\section{De la autobiografía}

Para qué fingir, seamos honestos, cuando se escribe, siempre se escribe (o se debe escribir) lo propio, lo personal. Para mí, la materia prima de la ficción es autobiográfica en el sentido más amplio del término: lo que uno ha vivido, soñado, imaginado, leído. Escribir es dejar (o provocar) que la experiencias vitales e intelectivas propias se acompañen, se mezclen, se confundan en el relato de ficción.

Creo que toda materia literaria parte de nuestra experiencia de la realidad ya sea para imitarla o modificarla, para evadirla o reinventarla.

\section{De la variedad y la variación}

He compuesto a lo largo de los años relatos de diferentes extensiones con algunas tendencias a lo experimental.

Aprecio la práctica de la variación como idea central en mi escritura, lo que implica el gusto por la variedad de artificios estilísticos, narratológicos, genéricos y temáticos.

En efecto, he cedido a sus tentaciones técnicas. Evoco algunas: la de narradores y formas dialógicas, desde la grandilocuencia hasta la paralipsis; la de mixturas genéricas, temáticas, estilísticas; la de inclusiones y anidamientos derivados de la mise en abyme; la de intertextualidaes y collages...

Ahora bien, a pesar de todo, en mi poética he buscado la densidad: concentrar, reducir, sintetizar. Un principio de selección, y de economía en donde nada sobre.

\section{Del artificio}

Los artificios son la clave y la cifra de la escritura literaria. 


\section{De los personajes}

Creo que los personajes -más que reales-deben ser convincentes: en su relación entre sí mismos y con respecto al espacio y al tiempo en los que se despliegan.

En su factura, el autor puede partir y parte de las personas del mundo de la realidad pero, sobre todo, los inventa, los construye, los ve, los inserta en el espacio de la ficción. Los personajes son palabras, pero palabras que actúan. El autor decide lo que hacen, pero ellos se rebelan, porque ya en algún momento tienen vida propia...

El autor está profundamente vinculado con todos y cada uno de ellos, aunque desde luego de maneras muy diferentes. Nunca podré decir stricto sensu que yo soy uno de mis personajes, pero sé bien que cada uno de ellos tiene algo de mí. Si bien los personajes literarios son ante todo un puñado de palabras, un hecho verbal y discursivo, estas palabras poseen el poder y la magia de configurar una imagen que precisa el lector en la complicidad de la lectura. Son voces y tonos de todos.

El placer y el poder de entrar y salir en los personajes, de convivir con ellos, de verlos y dirigirlos desde el palco o alternar y luchar con ellos en la escena. Ser el santo o el asesino, la amada o la ramera, el viejo o el niño, ser todos ellos en uno mismo.

\section{De la trama}

Me parece fundamental cuidar la lógica del relato de ficción, es decir, el orden y el encadenamiento de sus acciones.

Vale la pena comenzar por privilegiar el valor del enigma como incentivo de la curiosidad y terminar con un final sorpresa eficaz; o si se anuncia el final al principio del relato, privilegiar entonces la o las sorpresas que se encadenan a lo largo de la trama para llegar a ese final.

Es decir, puesto que el incipit de un relato es uno de sus momentos privilegiados, hay que intensificar sus valores de anuncio y vías de desarrollo de la historia. En mi caso personal, al escribir esas primeras líneas nunca he seguido una regla fija: en ocasiones ya conozco el final del relato, en otras, voy descubriendo - paso a paso, como el narrador y los personajes- el desarrollo de la historia y la que será su inevitable conclusión. A ese final único y asertivo que debe de ser el mejor; o, también, a esos otros finales suspendidos, interrumpidos o cíclicos que incitan a la pluralidad de las lecturas.

\section{De las finalidades}

Si escribo para ese otro, ese ser anónimo en el que busco el encuentro, la complicidad, solamente lo puedo hacer porque escribo para mí mismo, para ese otro que todos tenemos en nosotros mismos.

Escribo lo que es mi esencia, con la esperanza de que el lector descubra en ella la suya. 


\section{De la memoria}

No he olvidado algunos primeros ejercicios literarios - un par de cuentos y algún puñado de poemas- escritos entre los veinte y veinticinco años. Desde esos primeros ejercicios he cultivado un estricto sentido autocrítico y jamás los propuse a la publicación. Deben de reposar en las adormecidas hojas de viejos cuadernos.

\section{De los efectos de París}

París: la cosmópolis intercultural.

Si llegué a París para hacer estudios universitarios, llegué también con el mito de la escritura en París. Mito, pero también realidad, ya que desde mi llegada empecé a escribir un diario en el que coexistían textos de varia invención. Seleccioné entre ellos algunos poemas que aparecieron en una edición de autor en París en 1981. Un año después escribí un segundo poemario que se publicó en México y quedó en la terna finalista de un premio importante, pero no fue el ganador. Era muy joven y sin duda demasiado apasionado: me entró un enojo que se cristalizaría a lo largo de los años en una singular y paradójica vocación para un escritor, la de no seguir las etapas y los vericuetos de una carrera literaria. Si por una parte he mostrado siempre la desconfianza y distancia por las camarillas literarias y he evitado los coqueteos con el establishement de las letras -algunas facetas del «escritor profesional»- por otra parte, he persistido en el ejercicio vital y placentero de la escritura literaria.

Sí, durante años he llenado cuadernos con poemas; una selección de ellos la publico veinte años después en el volumen En las orillas del tiempo (2005).

Si a mediados de los años ochenta se me empezaron a dar los primeros cuentos, en 1992 escribí una novela que me sirvió para soltar la escritura y que he dejado reposar en algún cajón. Un año después empecé a escribir con regularidad relatos breves, cuentos principalmente, que aparecerían en los volúmenes de Los años vacíos, (2002). La dama sombría (2003) y La voz del mar (2006). Dentro de estos libros, hay narraciones de diferentes extensiones y géneros: cuentos breves de unas cuantas páginas, otros un poco más largos y por último una novela corta, Los años vacíos, homónima del libro. Su publicación precede otra novela corta, esta vez fantástico-policiaca: En la zona prohibida.

En estos dos relatos - que originalmente preveía como cuentos-, la trama fue creciendo de manera inevitable hasta que se convirtieron en novelas cortas. Su espacio genérico se sitúa entre dos fronteras principales la del cuento y la de la novela: por un lado, la concentración y la síntesis; por el otro, el despliegue y el desarrollo. Obras flexibles y fluctuantes que se explayan en una zona intermedia.

Si el cuento exige el rigor en la tensión y en el cuidado de detalles dada su brevedad, en la novela corta se permite el desarrollo sin renunciar del todo al rigor de la tensión.

En fin, uno siempre planta semillas verbales al principio de todo relato para que más tarde crezcan y se ramifiquen. Ya en función de sus ramificaciones se precisará el espacio genérico-literario. 
92 Tropelías. Revista de Teoría de la Literatura y Literatura Comparada, número extraordinario 2 (2017) Eduardo Ramos Izquierdo

\section{De la originalidad}

En el momento de la escritura se remueven las experiencias de mi pasado para poder aflorar en el lenguaje. Esas vivencias personales que se entremezclan con mis lecturas. Ignoro qué tanto este producto pueda ser -ah, el gran mito literario- novedoso o, mejor aún, original. Me interesa más lo intenso, lo distintivo, lo propio.

\section{De lo fantástico}

En mis cuentos fantásticos busco en el desarrollo de la trama una «coherencia» que no es, desde luego, la de la realidad de nuestro mundo empírico, pero sí la de una «lógica literaria» que sea convincente, aceptable para los personajes y para el lector.

Me gusta pensar que en nuestra existencia cotidiana hay hechos, cosas, situaciones, azares que resultan extraños y uno no consigue explicar con la razón. Cuando escribo algún relato de literatura fantástica también se inspira de experiencias personales, de algo que no me acabo de explicar bien. Me parece distinguir entonces una fisura que permite transitar a otro espacio, a otra zona que se convierte en el espacio, en la zona de la imaginación, de la creación, de la literatura.

\section{De lo policiaco}

El género policiaco canónico exige el rigor de la razón: el crimen presentado como enigma al principio de la historia se explica por el más puro encadenamiento de causas y efectos en el final. No hay sucesos sobrenaturales o mágicos, todo reside en la realidad y la razón.

Ese esquema racional puede ser tranquilizador: el lector del género policiaco se siente satisfecho de ver que, si al principio hay un problema, al final el criminal es descubierto y castigado. Dicho de otra manera, los problemas tienen respuesta, tienen solución: si en un principio el mundo es caótico, al final del texto se vuelve al orden.

Ahora bien, ese genéro canónico es, sobre todo, el punto de partida de una variabilidad, de una riqueza genérica que imita, mezcla y niega.

\section{De los espacios}

El viajar mucho y vivir fuera del país natal modifica fuertemente la percepción del espacio. Creo distinguir varios espacios en mis relatos de ficción. Desde luego que México y París son los espacios más evocados. No obstante, en algunos relatos no aparecen indicaciones de un espacio geográfico y tienen algo de un no-lugar que en realidad puede ser cualquier lugar de las aldeas y galaxias tan comentadas últimamente. 


\section{De la escritura y la corrección}

Se cuenta de Kafka que llegaba todas las noches a su casa a escribir compulsivamente y luego nunca corregía. Es una forma de escritura y me parece envidiable - dada la intensa calidad de su obrapoder escribir así. Ahora bien, hay otros escritores que vuelven y vuelven a sus textos: yo soy de esos... Para mí, la escritura literaria es un proceso de decantación.

\section{De las rutas y desvíos}

Nuestra vida es un tejido de un número infinito de instantes entre los que podemos distinguir algunos que nos parecen los decisivos. Esos instantes son también aquellos que determinan las etapas de elección de la trama en la escritura literaria. No obstante, cada instante, hasta el más nimio, es en potencia un punto de partida de la ficción.

\section{De la matemática, la música y el estilo}

Mi inclinación inicial por la matemática y la música en mi formación intelectual ha influido en mi percepción de la realidad y por ende en la escritura de mi ficción. Ambas materias son vías diferentes, la matemática es una ciencia y tiene una función demostrativa, la música es el arte por antonomasia de lo sonoro. Ahora bien, en ambas es fundamental la forma y la estructura de esa forma. En mi escritura literaria quizá aparezcan trazas de las dos - de manera manifiesta u oculta- en la organización de las partes y en su ritmo de articulación. La música está desde luego en la calidad sonora que busco tanto en la poesía como en la prosa; a pesar que distingo sus diferencias. Quizá pueda haber alguna métrica en determinados pasajes en la prosa, pero su ritmo, su respiración son distintos de los de la poesía. Por otra parte, aprecio el valor de lo sonoro -según la tradición estilística flaubertiana- de la lectura en voz alta en el momento de la escritura.

El estilo de un escritor es lo propio y distintivo de su obra, declinable en la expresión de sus temas y artificios, sus sensaciones y emociones, su alma y sus entrañas: su voz.

\section{Del misterio}

La exactitud de la palabra que privilegia la fuerza del sentido en el misterio de la creación literaria. 